\title{
THE DEVELOPMENT OF ENTREPRENEURIAL POTENTIAL AMONG HIGHER EDUCATION STUDENTS
}

\author{
Elina Varamäki and Sanna Joensuu \\ Business School, Seinäjoki University of Applied Sciences, Seinäjoki, Finland \\ Erno Tornikoski \\ Grenoble Ecole de Management, Grenoble, France, and \\ Anmari Viljamaa \\ Business School, Seinäjoki University of Applied Sciences, Seinäjoki, Finland
}

\begin{abstract}
Purpose - The purpose of this paper is to increase the understanding of how entrepreneurial potential is developed among young people. Changes in individuals' entrepreneurial intentions and the antecedents of intentions are investigated, as well as the impact of entrepreneurship education on the changes.

Design/methodology/approach - Ajzen's Theory of Planned Behavior (TPB) is applied. Longitudinal data from 197 HE students, in their first and third year of studies, is examined using path analysis.

Findings - Overall the entrepreneurial intentions of HE students decreased over time. Intentions decreased particularly for those with high initial level of intentions, whereas the group with increasing intentions rose from low to neutral level of intentions. Changes in attitudes and perceived behavioral control have a significant positive impact. Versatile entrepreneurship courses have direct effect on changes in attitudes. Changes in attitudes have a dual role, as they influence change in both intentions and perceived behavioral control. The developed model explains 19 percent of the variance among women and 28 percent among men, suggesting gender differences in development of intentions.
\end{abstract}

Research limitations/implications - Only one way of developing entrepreneurial potential in young people (i.e. education) is covered. The empirical sample is limited to one university.

Practical implications - The results suggest versatile methods of entrepreneurship education are more effective in developing intentions than perhaps purely active modes. Gender differences should be considered when designing interventions to foster entrepreneurial potential.

Originality/value - The research confirms with longitudinal individual-level data the applicability of TPB on entrepreneurial intentions and demonstrates the mediated impact of versatile entrepreneurship courses on changes in intentions.

Keywords: Longitudinal data, Entrepreneurial intention, University, Entrepreneurship, Student

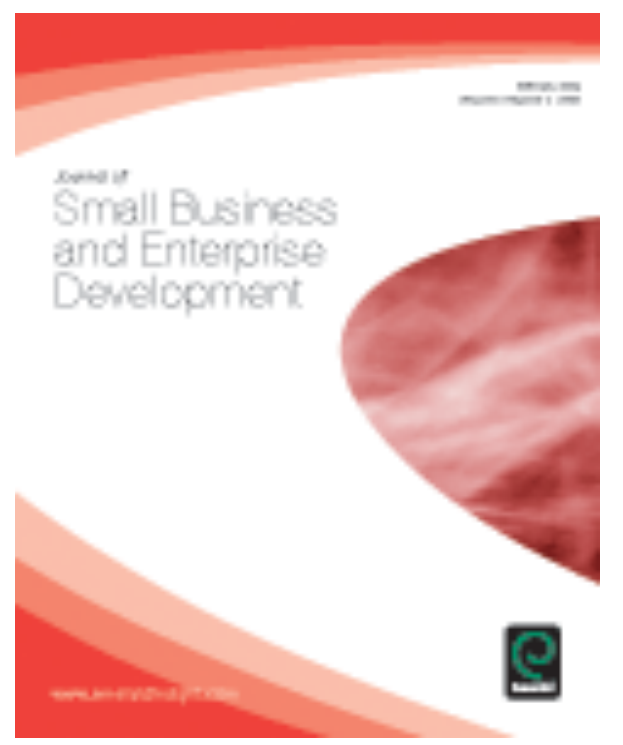




\section{INTRODUCTION}

In current societies, especially in Western countries, a large number of initiatives to promote entrepreneurial actions have been introduced in order to respond to different societal challenges (such as aging population, regional inequalities, etc.). To this end, education is one of the more common ways through which entrepreneurial potential is promoted and hence one of the key areas where we should investigate the impact of entrepreneurship initiatives at individual level. Longitudinal studies on the subject, however, are relatively few (Matlay and Carey, 2007), and pose formidable data collection challenges (e.g. Harte and Stewart, 2010).

As an interesting contribution to this discussion, Jones and Iredale (2010) distinguish between enterprise education with focus on personal attributes and skills that can be used in a variety of contexts and entrepreneurship education with focus on starting and running a business. Some scholars seem to opt for the latter approach. For example, it has been argued that research on impacts of entrepreneurship training should extend to longitudinal studies that examine actual venture formation (Matlay, 2005; Pittaway and Cope, 2007). For the development of entrepreneurial potential through educational programs, it has to be noted, however, that not all such initiatives aim to 'producing' new entrepreneurs, e.g. individuals who would actually start their own business during the initiative or right after it. Indeed, there is an on-going debate on the proper aims and scope of entrepreneurship education (e.g. Gibb, 2002; Mwasalwiba, 2010).

In this study we adhere to the principles of enterprise education in which the focus is on the development of personal attributes and perceived skills related to entrepreneurship, rather than on the final act of starting a business. Our choice is motivated by the fact that the actual rate of startup creation is influenced also by factors outside the scope of educational institutions (e.g. economic downswings); an individual's attributes and perceived skills related to entrepreneurship are something that education can reasonably aim to influence.

Furthermore, our study is motivated by two issues. First, scholars do not seem to agree whether there is a positive or negative relation between education and the development of personal attributes and perceived skills related to entrepreneurship. For example, some scholarly work found evidence that entrepreneurship related education has a positive influence, for example, on intentions, attitudes and self-efficacy (e.g. Zhao et al., 2005; Souitaris et al., 2007; Jones et al., 2008; Wilson et al., 2009). Other scholars however have observed a negative relationship between enterprise education and entrepreneurial attributes and skills (e.g. Pihkala and Miettinen, 2004; Oosterbek et al., 2010). As such, it is not clear what kind of link is there between getting a higher education diploma and the development of entrepreneurial potential. 
Second, the choice of a particular pedagogy inside an educational program can also have an impact on the development of entrepreneurial potential, besides the mere fact that someone would participate in higher education program in general. So, as a micro perspective in entrepreneurship education, we should pay attention to the particular ways we teach and deliver entrepreneurship related programs. Previous research suggests that entrepreneurship teaching should by based on more active, learning-by-doing pedagogies rather than passive pedagogies dependent on books and lectures, in order to develop students' competence and confidence in their skills as individuals (e.g. Henry and Treanor, 2012; Neck and Greene, 2011; van Gelderen, 2010; Walter et al., 2010; Bennett, 2006; Dana, 1987). Yet, for example Pittaway and Cope (2007) call for comparative studies, over time, to evaluate pedagogies in relation to alternatives. More research is needed in this respect to better understand the micro-dynamics of effective entrepreneurship pedagogy.

So far we have not identified longitudinal studies on individual level comparing the impacts of different pedagogical approaches (i.e. active-based and lecture-based teaching) on personal attributes and perceived skills related to entrepreneurship, and whether these in turn lead to increased entrepreneurial potential. Therefore, in this study we aim to make a contribution to this direction. The overall purpose of our study is to increase our understanding about the usefulness of enterprise education in general, on the one hand, and different pedagogical approaches, on the other hand, on the development of entrepreneurial potential among higher education students. The more specific objective of our study is to investigate the impact of different pedagogical approaches on the development of personal attributes and perceived skills related to entrepreneurship, and the impact of such development on entrepreneurial potential among higher education students.

While our study is not the first to investigate the role of higher education in the development of entrepreneurial potential, we make a systematic effort to follow the development of an individual's personal attributes and perceived skills during his/her studies. The timeline of our study is three years, and we follow the same individuals, not a cohort of individuals. As such, the overall contribution of our study is related to the systematic study of the development of entrepreneurship related personal attributes and perceived skills during three-year studies in the Finnish higher education system.

The rest of the paper is organized as follows. In the next section, we will propose a conceptual model for the development of entrepreneurial potential. The model is largely inspired by the literature related to the development of (entrepreneurial) intention. We will explicate why it is important to focus on intention as a proxy for the development of entrepreneurial potential. We will also specify the personal attributes and perceived skills important for the development of 
entrepreneurial intention. Finally, we integrate a new conceptual piece to the model in the form of entrepreneurship pedagogy. In the section that follows the conceptual model, we discuss our methodological choices and the statistical methods before presenting the empirical results. In the last section, we discuss the implications of our study.

\section{A CONCEPTUAL MODEL OF ENTREPRENEURIAL POTENTIAL}

\section{Intention as proxy for entrepreneurial potential}

In this study we adopt the standpoint that personal attributes and perceived skills are suitable for examining and comparing educational endeavors and their impact on the development of entrepreneurial potential of individuals. Indeed, one of the central objectives of entrepreneurship related programs is to develop entrepreneurial potential, i.e. the degree to which an individual possesses entrepreneurial qualities (Thompson, 2004; Raab et al., 2005), and the number of individuals that possess them, and through this development, increase the number of potential new business creators in the future.

We focus on the concept of entrepreneurial intention -defined as the commitment to starting a new business (Krueger and Carsrud, 1993) after graduation directly or later in the career- as a proxy to indicate whether entrepreneurial potential has indeed been developed. We offer two reasons for this particular focus on entrepreneurial intention.

First, because entrepreneurial potential "is latent and is causally and temporally prior to intentions" (Krueger and Brazeal, 1994, 91), it makes sense to focus on entrepreneurial intention as an outcome of entrepreneurial potential. That is, if entrepreneurial potential has increased, then it should show in increase in entrepreneurial intention. Second, the decision to focus on intention, as a proxy to entrepreneurial potential, is also motivated by its close linkage to realized behavior. Indeed, the intention to perform a behavior has been described as the best single predictor of an individual's actual behavior (Fishbein and Ajzen, 1975; Bagozzi et al., 1989; Krueger and Carsrud, 1993). As such, entrepreneurial intention is the best available measure of entrepreneurial potential, because it directly precedes a decision to start a business. Recent empirical evidence confirms that entrepreneurial intentions seem to predict well future start-up behavior (e.g. Kautonen, van Gelderen, Tornikoski, in press), and as such, offers strong validity to the decision to use entrepreneurial intention as a proxy of entrepreneurial potential.

\section{Antecedents of intentions: personal attributes and perceived skills}


In order to understand how entrepreneurial intentions are formed -that is, what personal attributes, skills, and other self-perceived mental positions are connected to intention formation-we start by adopting the Theory of Planned Behavior (TPB) developed by Ajzen (1991). We choose TPB because of its detailed and consistent theoretical specification and the great amount of crossdisciplinary research devoted to testing, advancing and criticizing the intention model (Armitage and Conner, 2001; Sheeran, 2002). In addition, the TPB has been regarded particularly appropriate for the evaluation of entrepreneurship related programs (e.g. Fayolle, 2005; Nabi et al., 2010), which is why it has been widely used not only amongst older people (e.g. Tornikoski \& Kautonen, 2009), but also amongst younger individuals.

As examples, Krueger (1993) and Krueger, Reilly and Carsrud (2000) looked at the entrepreneurial intentions of US university business students, whereas Fayolle, Gailly and LassasClerc (2005) focused on students in a French elite business school. Kolvereid (1996) investigated the employment status choice intentions of Norwegian undergraduate business students, Tkachev and Kolvereid (1999) studied the entrepreneurial intentions of Russian students and Autio et al. (2001) Scandinavian and US students (see also Devonish et al., 2010). As such, the applicability of the TPB model to the study of the development of entrepreneurial intentions, and therefore entrepreneurial potential, among young people spans multiple contexts.

The core of the TPB is the idea that intentions have three conceptually independent determinants, namely attitude towards the behavior, subjective norm and perceived behavioral control (Ajzen, 1991, p. 188). Attitude towards the behavior refers to the degree to which a person has a favorable or unfavorable evaluation or appraisal of the behavior in question. The more positive an individual's perception is regarding the outcome of starting a business (see e.g. Shapero \& Sokol, 1982; Autio et al., 1997; Krueger et al., 2000; Segal et al., 2005; Van Gelderen and Jansen, 2006; Pruett et al., 2009) the more favourable their attitude towards that behaviour should be and, consequently, the stronger the individual's intention to go ahead and start a business should be. In our study, we take entrepreneurial attitude as a personal attribute that can be influenced during an educational program.

Subjective norm refers to the perceived social pressure to perform or not to perform a specific behavior. It is based on beliefs concerning whether important referent individuals or groups approve or disapprove of an individual establishing a business, and to what extent this approval or disapproval matters to the individual (Ajzen, 1991, p. 195). Generally speaking, the more the opinion of a particular referent group or individual matters to the individual and the more encouraging the individual thinks it is of enterprising activity, the stronger should be the 
individual's intention to start a business. In our study, we take subjective norm as a personal attribute that can be influenced during an educational program.

Perceived behavioral control refers to the perceived ease or difficulty of performing the behavior. It is based on beliefs regarding the presence or absence of requisite resources and opportunities for performing a given behavior (see Bandura et al., 1980; Swan et al., 2007). In general, the greater this perceived behavioural control, the stronger the individual's intention to start up in business should be. According to Ajzen (1991) this is most compatible with Bandura's (1982) concept of perceived self-efficacy. In our study, we take perceived behavioral control as a perception of skills that can be influenced during an educational program.

According to Ajzen and Fishbein (2004), the three theoretical antecedents should be sufficient to predict intentions, but only one or two may be necessary in any given application. In other words, the theory of planned behavior posits that the relative importance of the three factors can vary from one context to another. When using these three antecedents of entrepreneurial intentions to understand whether education impacts entrepreneurial intentions, and hence entrepreneurial potential of an individual, we acknowledge that the results we get are always context dependent.

As a sum, in this study we try to understand the development of entrepreneurial potential using an intention model, which is based on three personal attributes and perceived skills, namely perceived behavioral control, entrepreneurial attitudes, and subjective norm (see Figure 1).

\section{Education in general and intentions}

The impact of education on entrepreneurial intentions has been studied at least by Lee et al. (2011), Wilson et al. (2007), Sandhu et al. (2011), Millman et al. (2010), Nabi et al. (2010), Henley (2005), Franco et al. (2010), Fayolle at al. (2005), Blanchflower and Meyer (1994), and Kristiansen and Indarti (2004). At the general level, some studies suggest that higher education reduces the likelihood of entrepreneurship (Henley, 2007; Pihkala, 2008; Wu and Wu, 2008; Nabi et al., 2010). Others seem to show the opposite. For example, it was observed among Spanish university students that education had a positive effect on perceived entrepreneurship feasibility, which in turn affected entrepreneurial intention and behavior (Lanero et al., 2011). Blanchflower and Meyer (1994) found that additional years of schooling had a positive impact on the probability of being self-employed in the USA but not in Australia. Turkish senior students are more likely to have entrepreneurial intentions than freshmen (Ertuna and Gurel, 2011).

Considerable research effort has also been put to understanding the effects of entrepreneurship education in particular (Matlay and Carey, 2007; Mwasalwiba, 2010). Matlay (2008) shows 
students with entrepreneurial intent can benefit from entrepreneurship education, but results for more general student populations remain equivocal. Studies show positive impacts of entrepreneurship education on intentions, attitudes and self-efficacy (e.g. Zhao et al., 2005; Souitaris et al., 2007; Jones et al., 2008; Wilson et al., 2009), but also negative impacts have been reported (e.g. Pihkala and Miettinen, 2004; Oosterbek et al., 2010). Packham et al. (2010) found an entrepreneurship course to have positive attitudinal effects for Polish and French students but negative effects for German students, with further differences between genders. Drost and McGuire's (2011) study of Finnish business students finds that entrepreneurship education (measured as students' self-reported learning on specific skills) has a positive impact on entrepreneurial intent, but the effect is mediated by entrepreneurial self-efficacy. In Pihkala's (2008) study entrepreneurial education decreased entrepreneurial self-efficacy, which is related to perceived behavioral control. Hytti et al. (2010) suggest that the effectiveness of entrepreneurship courses may vary depending on the motivation of the students taking part. Fayolle et al. (2005) examined the effect of three day seminar on entrepreneurship among college students. They found a positive impact of this program on perceived behavioral control and subjective norms, but only for students not previously exposed for entrepreneurship in their family context.

In this study we try to understand the development of entrepreneurial potential while an individual is participating in an educational program. Intuitively we join those who question the positive impact of higher educational program on an individual's entrepreneurial potential in general: there are relatively little reasons to believe that an educational program as such would automatically increase the entrepreneurial potential of individuals. A more intriguing question is whether the type of pedagogy used in entrepreneurship courses would have an impact on entrepreneurial potential.

\section{Entrepreneurship pedagogy and intentions}

The final piece of our conceptual model of entrepreneurial potential is related to entrepreneurship pedagogy. Although many higher education institutes aim to encourage the development of entrepreneurial behavior of their students, it is not unreasonable to expect that the way we teach entrepreneurship could also have particular effects on the participants and their entrepreneurial potential.

Bennett (2006) distinguishes between skills training approach and attribute development approach in entrepreneurship education. The former is more focused on management skills while the latter emphasizes attitudes, self-determination and innovativeness. Mwasalwiba's (2010) 
analysis shows that entrepreneurship education is shifting towards emphasis on attitudes; there is a fair level of agreement on that students who will in the future be self-employed need a more actionbased approach (see also Gibb, 2002; Gibb, 1996). Previous research suggests that entrepreneurship education should not be promoting passive reception of information, and that enabling students to "learn by doing" is more effective on skills and attitudes (e.g. European Commission, 2012; Henry and Treanor, 2012; Neck and Greene, 2011; Walter et al., 2010; Dana, 1987). Hence, it is tempting to argue that active-based pedagogy in entrepreneurship courses is more likely to influence students' entrepreneurial potential in a positive manner compared to lecture-based pedagogy.

As a result of this discussion, we propose that the way we teach entrepreneurs (entrepreneurship pedagogy) has an impact on the three antecedents of entrepreneurial intentions, namely entrepreneurial attitudes, perceived behavioral control, and subjective norm (see Figure 1). Based on the above conceptual development, the following Figure 1 presents our conceptual model of entrepreneurial potential.

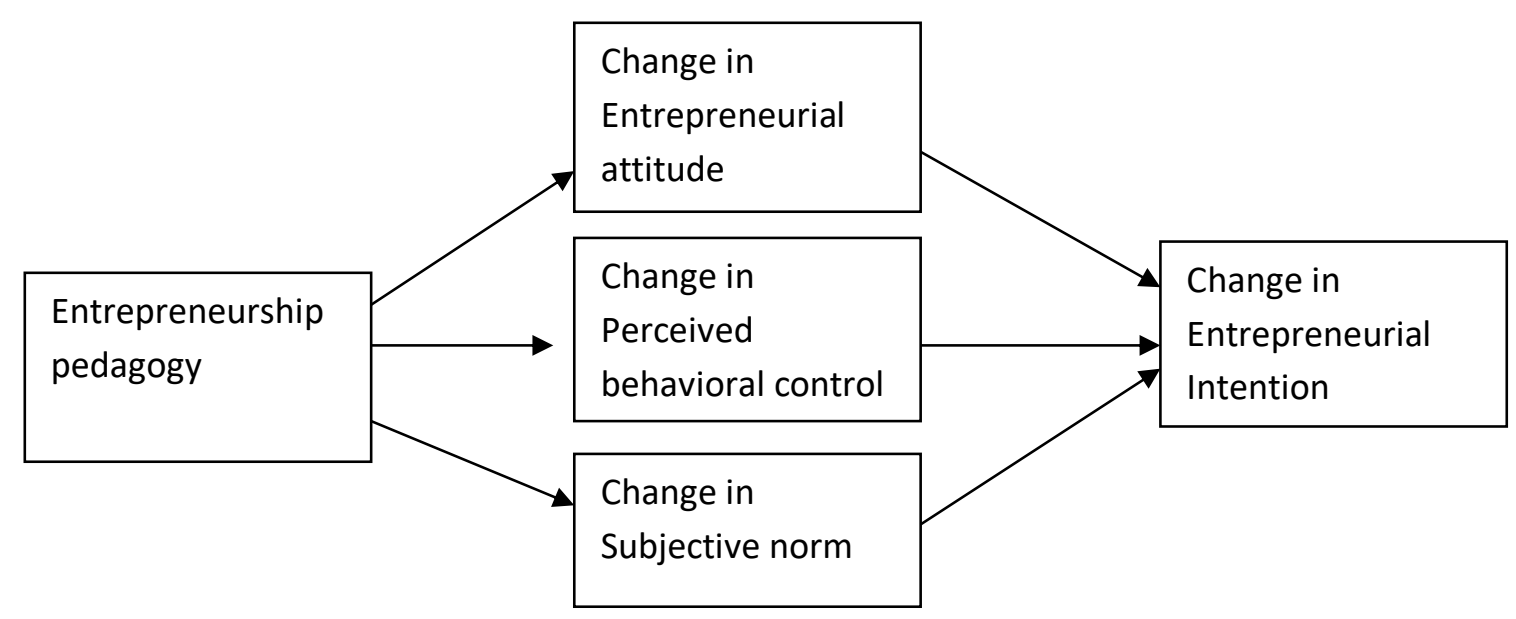

Figure 1. The Conceptual Model of Entrepreneurial Potential.

\section{METHODOLOGY}

The empirical context of our study is located in Finland, and more specifically in South Ostrobotnia in the Seinäjoki University of Applied Sciences. The provision of some level of entrepreneurship education on all levels of schooling has been a stated policy objective in Finland since the 90's (Pihkala, 2008). Higher education institutions have considerably increasing their 
efforts to promote entrepreneurship in the $21^{\text {st }}$ century. For Seinäjoki University of Applied Sciences entrepreneurship is one of its strategic areas of emphasis.

\section{Instrument and data collection method}

The scales for each variable were developed largely based on Kolvereid (1996). However, in some parts of the instrument (for example attitudes), new scales were proposed and tested using national data during 2008-2009. The data for this study was collected using a self-administered questionnaire in fall 2008 and 2010. Paper copies of the questionnaire were administrated to students during their classroom time by teachers.

In autumn 2008, 534 responses from first year students were received (response rate app. 53 percent), and in autumn 2010, 197 responses from the same individuals were received. The followup study is based on this data (197 responses from $1^{\text {st }}$ to $3^{\text {rd }}$ study-year). The students were from six different study fields (business, culture, natural resources, social services and health, technology and tourism and catering).

\section{Variables}

Entrepreneurial Intentions. An index of entrepreneurial intention was created by averaging eight items $(\min =1, \max =6.1$, mean=3.3, Std. Dev.=1.1). The variable demonstrates good reliability (Cronbach's Alpha=0.86). All the variables and their items are presented in Appendix 1.

Subjective Norm. The variable Subjective Norm has three items. Originally each item had a seven-point scale from 1-7. For the statistical analysis the scales were transformed to $-3-+3$ scale. In addition, motivation to comply was measured by three items (seven-point scale from 1 to 7 ) referring to each of the aforementioned belief questions. The belief based items (coded as ranging from -3 to 3 ) and the corresponding motivation to comply items (coded as ranging from 1 to 7 ) were multiplied, and then added to create an index of Subjective Norm $(\min =-43, \max =54$, mean $=-0.5$ Std. Dev. = 15.7). The variable demonstrates acceptable reliability (Cronbach's Alpha $=0.73$ ).

Perceived Behavioral Control. An index of Perceived Behavioral Control was created by averaging five item scores $(\min =1.6 \max =6.8, \operatorname{mean}=4.1$, Std. Dev. 1.0). The variable demonstrates acceptable reliability (Cronbach's Alpha $=0.71$ ).

Entrepreneurial Attitude. An index of Entrepreneurial Attitude was created by averaging nine item scores $(\min =2.3 \max =7$, mean $=5.0, \mathrm{Std} . \mathrm{Dv} .=0.8)$. The variable demonstrates acceptable reliability (Cronbach's Alpha=0.75). 
Entrepreneurship Pedagogy. Respondents were asked if they participated in entrepreneurship courses during their studies. This was further categorized in two options: participation in lecturingbased entrepreneurship courses only (lecture-based pedagogy), and participation in both activebased and lecturing-based entrepreneurship courses (active-based pedagogy). Active-based entrepreneurship courses refer, for example, to co-operating with real companies in projects, making a business plan or managing a virtual enterprise. Active-based entrepreneurship pedagogy includes both kinds of courses, as it would have been unlikely that a student would have no lecturing-based courses. Entrepreneurship pedagogy (active-based pedagogy) was included in the analysis as a dummy variable with the value one given to respondents who indicated that they participated both in active- and lecturing- based courses and a value of zero given to respondents participating only in lecturing-based courses.

\section{Control variables}

Gender. Since research has shown that women have less desire to start new businesses than men (e.g. Crant, 1996; Kourislky and Walstad, 1998; Wang and Wong, 2004; Wilson et al., 2004; Shay and Terjesen, 2005; Sequeira et al., 2007; Linan and Chen, 2009; cf. Pruett et al., 2009; Kautonen et al., 2010; Yordanova and Tarrazon, 2010; Lee et al., 2011), gender is going to be controlled as part of the statistical analysis.

\section{Analytical methods}

The conceptual model of entrepreneurial potential was tested using structural equation modelling. In the statistical analysis, path analysis was conducted using SPSS Amos. Path analysis is an extension of multiple regression. It enables the usage of more complicated models and can examine situations in which there are several dependent variables and those in which there are chains of influence (Steiner, 2005, 115). One must bear in mind that path analysis cannot be used to establish causality; that is done through the design of the study (Steiner, 2005, p. 122).

For the path analysis, we calculated difference scores for each of the main variables of the TPB model (Entrepreneurial intention, Subjective norm, Entrepreneurial attitudes, Perceived behavioral control). Clarke (2004) states that it is common to use the difference score when studying change from 2-wave data. The difference score is simply the difference between the wave 2 score and the wave 1 score (or vice versa). Clarke (2004) also argues that although objections have been raised about using the difference score to measure change (ceiling and floor effects, regression to the mean, and measurement error), it has been demonstrated that these problems are not inherent and 
that the difference score is a valid measure of change. We calculated each time a change variable by subtracting the 2010 value from the 2008 value (e.g. Intention2010 minus Intention2008). As such, we investigated whether changes in intentions were the result of changes in attitudes, in subjective norm and in perceived behavioral control.

\section{Common method variance}

We tested the possible effects of common method variance for the variables collected using Harman's one factor test (Harman, 1976). If common method variance was a serious problem in the study, we would expect a single factor to emerge from a factor analysis or one general factor to account for most of the covariances in the independent and dependent variables (Podsakoff and Organ, 1986). All the items used to create the main variables, a total of 29 items, were factor analysed using principal axis factoring where the unrotated factor solution was examined, as recommended by Podsakoff, MacKenzie, Lee and Podsakoff (2003, p. 889). Kaiser's criterion for retention of factors was followed. The sample size seemed to be large enough for the factor analysis, at least based on the Kaiser-Meyer-Olkin measure of sampling adequacy $(\mathrm{KMO}=0.69)$.

Factor analytic results indicated the existence of eight factors with eigenvalues greater than 1.0. The eight factors explained 71 percent of the variance among the 29 items, and the first factor accounted for 26 percent of the variance. Since several factors, as opposed to one single factor, were identified and since the first factor did not account for the majority of the variance, a substantial amount of common method variance does not appear to be present. Thus, we conclude that common method variance bias is not a threat to the validity of the results. One should bear in mind though that this procedure does nothing to statistically control for the common method effect: it is just a diagnostic technique (Podsakoff et al., 2003, 889). Hence, the possibility of common method issues cannot be fully discarded.

\section{Respondents}

The mean age of the respondents was 23 in 2010. 61 percent of the respondents were female. Table 1 describes the earlier experiences of the respondents before their entered their studies.

\begin{tabular}{ll}
\hline Background characteristics of the respondents & Total sample \\
\hline Earlier participation in entrepreneurship courses & $22 \%$ \\
\hline Earlier work experience (more than 6 months) & $50 \%$ \\
\hline Mother's professional background as an entrepreneur & $21 \%$ \\
\hline Father's professional background as an entrepreneur & $37 \%$ \\
\hline
\end{tabular}


Table 1. Earlier experiences of respondents.

When comparing background characteristics within gender, we found that men had more work experience than women. 63 percent of men and 43 percent of women had earlier work experience. The difference was statistically significant. No other differences related to gender and background characteristics were found.

\section{EMPIRICAL RESULTS}

Correlations among the variables in the model are presented in Appendix 5. Tolerance and VIFvalues were analyzed to see that there was not a threat of multicollinearity between independent variables.

\section{Education in general and entrepreneurial potential}

As far as the effects of education on entrepreneurial potential are concerned, our empirical findings could be summarized as follows. First, all the studied variables related to the TPB model either decreased (i.e. Entrepreneurial intentions, Entrepreneurial attitudes, and Subjective norm) or stayed the same (Perceived behavioral control) during the educational program (see Table 2). As such, higher education in general does not seem to increase entrepreneurial potential.

Second, and more interestingly, there was a statistically significant difference between those students who were exposed to lecture-based pedagogy and the students who experienced activebased pedagogy. More particularly, active-based entrepreneurship pedagogy seems to keep the studied variables at the same level during the educational program. Whereas, following lecturebased pedagogy, we witnessed the same decreasing tendency as with the whole population (see Table 2). As such, it seems that active-based entrepreneurship pedagogy conserved entrepreneurial potential, whereas lecture-based pedagogy decreased entrepreneurial potential in the studied sample.

\begin{tabular}{lcccc}
\hline Variable & $\begin{array}{c}\text { Entrepreneurial } \\
\text { intentions }\end{array}$ & $\begin{array}{c}\text { Subjective } \\
\text { norm* }\end{array}$ & $\begin{array}{c}\text { Entrepreneurial } \\
\text { attitudes }\end{array}$ & $\begin{array}{c}\text { Perceived } \\
\text { behavioral control }\end{array}$ \\
\hline $\begin{array}{l}\text { Total sample } \\
(\mathbf{n = 1 9 7 )}\end{array}$ & $3.3(1.09)$ & $-0.53(15.65)$ & $5.0(0.77)$ & $4.1(0.96)$ \\
$1^{\text {st }}$ year & $3.2(1.09)$ & $-3.3(15.75)$ & $4.9(0.82)$ & $4.1(0.99)$ \\
$3^{\text {rd }}$ year & $* *$ & $*$ & $*$ & - \\
Sig. & & & & \\
\hline
\end{tabular}

Active-based 


\begin{tabular}{lcccc}
\hline pedagogy $(\mathbf{n}=\mathbf{4 3})$ & $3.6(1.06)$ & $0.3(19.98)$ & $5.1(0.71)$ & $4.3(1.00)$ \\
$1^{\text {st }}$ year & $3.4(1.06)$ & $-3.0(17.53)$ & $5.1(0.73)$ & $4.3(1.12)$ \\
$3^{\text {rd }}$ year & - & - & - & - \\
Sig. & & & & \\
\hline & & & & \\
\hline Lecture-based & & & & \\
pedagogy $(\mathbf{n}=\mathbf{2 3})$ & $3.5(1.10)$ & $-3.1(14.15)$ & $5.2(0.67)$ & $4.2(1.19)$ \\
$1^{\text {st }}$ year & $3.0(0.97)$ & $-6.9(17.06)$ & $4.7(0.67)$ & $4.0(0.93)$ \\
$3^{\text {rd } \text { year }}$ & $* * *$ & $*$ & $* *$ & - \\
Sig. & & & &
\end{tabular}

Table 2. Changes in Entrepreneurial attitudes, Subjective norm, Perceived behavioral control, and Entrepreneurial intentions during educational program.

We observed some gender related differences. Among female students, intentions and attitudes decreased statistically significantly in comparison to male students. Among male students, intentions and attitudes remained the same but subjective norm decreased. In addition, when we used the earlier experiences of the respondents (listed in the Table 1) in the role of control variables, we failed to observe any differences across the different experiences. Finally, an interesting, and statistically significant, observation relates to the fathers' and mothers' background as entrepreneurs: these two variables affected the initial level of intentions (level of intention when entering the first year), but did not contribute to the development of entrepreneurial intentions over time. That is, those who had either a mother or father as an entrepreneur had higher initial level of entrepreneurial intentions. And yet, those two background characteristics did not impact the development of entrepreneurial intentions during an educational program.

As an ad-hoc analysis ${ }^{1}$, we were interested in discovering patterns inside the student population (see Table 3 for results). For example, we identified 46 students with a high initial level of intention $^{2}$. The level of intentions of these students fell significantly $(p=0.000)$ during the educational program. Respondents with a low initial level of intention (151 students), on the contrary, did not experience a significant change during the educational program. These results are similar to Fayolle et al.'s (2005) findings. Furthermore, as can be seen from the Table 3, there are 71 respondents who experienced a positive change in intentions during the educational program.

\footnotetext{
${ }^{1}$ We thank one of the anonymoys reviewers for suggesting this ad-hoc analysis.

${ }^{2}$ We classified someone as having a high level of intention when he/she scored over 4 and a low level of intention when the score was 4 or below (scale 1-7).
} 
These students had a relative low initial level of intention (mean 2.9), which then rose to a significantly to a relatively neutral level (mean 3.7 in 1-7 scale) during the educational program. The profiles of these groups can be found in Appendix 4.

\begin{tabular}{llll}
\hline Entrepreneurial intention & $1^{\text {st }}$ year (mean, sd.) & $3^{\text {rd }}$ year $($ mean, sd.) & sig. (t-test) \\
\hline Respondents with a high initial level of intention $(\mathrm{n}=46)$ & $4.8(0.57)$ & $4.2(1.03)$ & $* * *$ \\
\hline Respondents with a low initial level of intention $(\mathrm{n}=151)$ & $2.8(0.71)$ & $2.8(0.90)$ & - \\
\hline Respondents with a positive change in intention $(\mathrm{n}=71)$ & $2.9(1.00)$ & $3.7(1.11)$ & $* * *$ \\
\hline Respondents with a negative change in intention $(\mathrm{n}=126)$ & $3.5(1.07)$ & $2.9(0.97)$ & $* * *$ \\
\hline
\end{tabular}

Table 3. Changes in Entrepreneurial attitudes, Subjective norm, Perceived behavioral control, and Entrepreneurial intentions during the educational program for different sub-groups of students.

\section{Antecedents of intentions: personal attributes and perceived skills}

As discussed earlier, the conceptual model of entrepreneurial potential was tested using structural equation modelling. Although RMSEA (0.063) and CMIN/DF (1.771) values were acceptable, other fit measures indicated an inadequate fit (NFI $=0.897$; CFI $=0.94)$. After some explorations, we discovered, for example, that the Change in Entrepreneurial attitudes fully mediated the effect of Entrepreneurship pedagogy to the Change in PBC and to the Change in Entrepreneurial intentions.

As a result of our exploration efforts, the Figure 2 presents the final empirical model of Entrepreneurial Potential. For this empirical model, all the fit measures are good $(\mathrm{CFI}=1.00 ; \mathrm{NFI}=$ $0.99 ; \mathrm{RMSEA}=0.000 ; \mathrm{CMIN} / \mathrm{DF}=0.178$ ). In addition, the squared multiple correlation of a variable is the proportion of its variance that is accounted for by its predictors (Arbuckle, 2007). As can be seen from the Figure 2, the empirical model of Entrepreneurial Potential explains $22 \%$ of the variance in the intention development. 


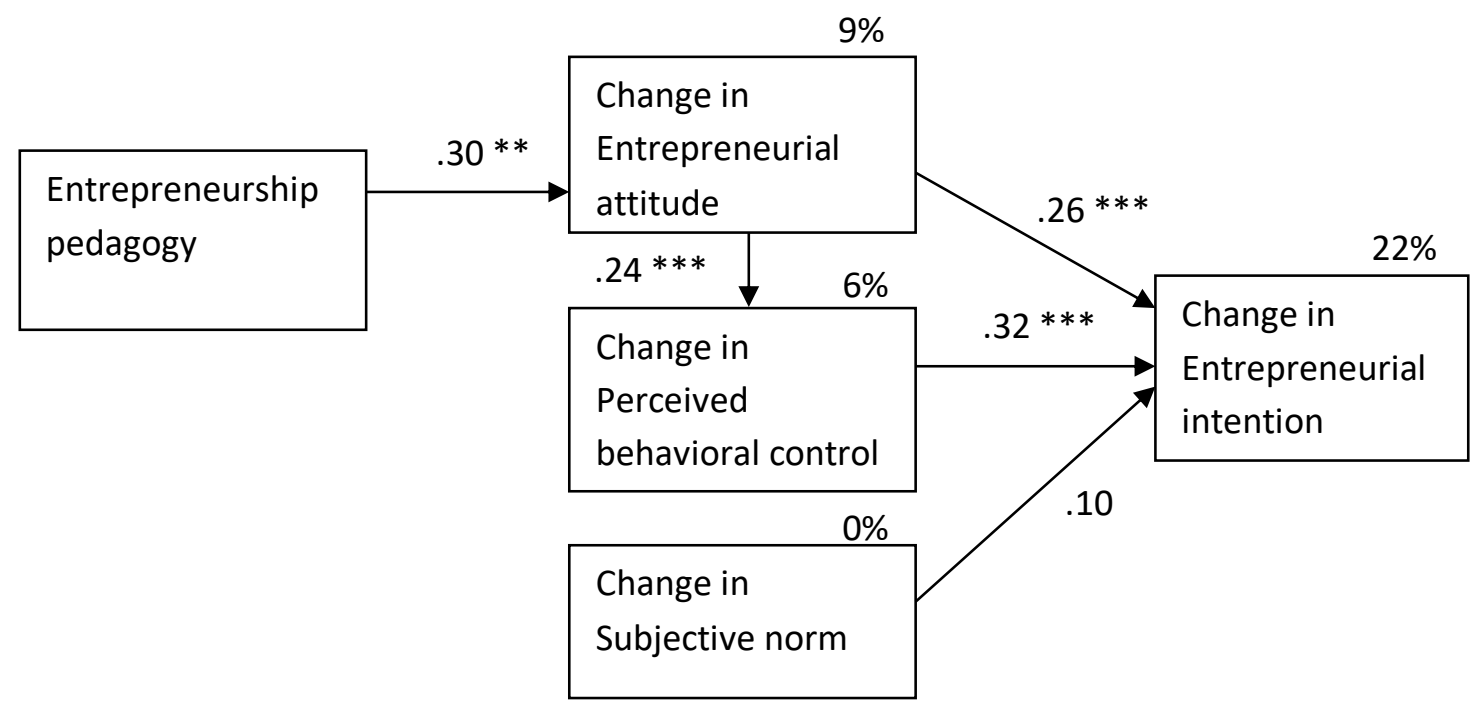

Notes: chi-square $=0.890, \mathrm{df}=5, \mathrm{p}=0.971, \mathrm{CMIN} / \mathrm{DF}=0.178, \mathrm{CFI}=1.000, \mathrm{NFI}=0.987, \mathrm{RMSEA}=0.000$ $+\mathrm{p}<.10{ }^{*} \mathrm{p}<.05 . * * \mathrm{p}<.01 . * * * \mathrm{p}<.001$

Figure 2. The Empirical Model of Entrepreneurial Potential.

The Table 6 shows the regression estimates between the Change in Entrepreneurial intentions and its determinants and p-values for significance.

\begin{tabular}{lllrrrrr}
\hline & & & Estimate & S.E. & C.R. & P & Standardized Regression Weights \\
\hline ATTchange & $<---$ & Ent.pedagogy. &, 426 &, 158 & 2,685 &, 007 &, 299 \\
PBCchange & $<---$ & ATTchange &, 297 &, 086 & 3,471 & $* * *$ &, 241 \\
EIchange & $<---$ & ATTchange &, 337 &, 085 & 3,979 & $* * *$ &, 259 \\
EIchange & $<---$ & PBCchange &, 343 &, 069 & 4,992 & $* * *$ &, 324 \\
EIchange & $<---$ & SNchange &, 006 &, 003 & 1,632 &, 103 &, 103 \\
\hline
\end{tabular}

Table 6. Estimates and Standardized Regression Weights of the Empirical Model of Entrepreneurial Potential.

As can be seen from the Table 6, Change in Entrepreneurial attitude had a significant and positive impact on the Change in Entrepreneurial intention $(\mathrm{p}<0.001)$. Also, Change in Perceived behavioural control has a significant and positive impact on the Change in Entrepreneurial intention $(\mathrm{p}<0.001)$. The relationship between Change in Subjective norm and Change in Entrepreneurial intention was not significant. Furthermore, Entrepreneurship pedagogy had a significant and positive impact on the Change in Entrepreneurial attitude $(\mathrm{p}<0.01)$. The Change in 
Entrepreneurial attitude has also a positive impact on the Change in Perceived behavioral control $(\mathrm{p}<0.001)$.

In addition, we observed interesting gender differences when running the above analysis for both groups (see the Appendixes 6 and 7 for results). First, among women, Entrepreneurship pedagogy does not have any significant effects on any of the studied variables. Among men, however, this effect exits. Second, the Change in Entrepreneurial attitudes has no effect on the Change in Perceived behavioral control among women. Again, among men this effect exists. Third, among women, the empirical model of entrepreneurial potential explains $19 \%$ of the variance, whereas among men the model explains $28 \%$.

\section{DISCUSSION AND CONCLUSIONS}

The overall purpose of our study was to increase our understanding about the usefulness of enterprise education in general, on the one hand, and different kinds of pedagogical approaches, on the other hand, on the development of entrepreneurial potential among higher education students. Using an interesting sample from one Finnish University, where we followed the development of entrepreneurial potential at the individual level during three years, we were able to find evidence to conclude that higher education in general seems to have a negative impact on the development of entrepreneurial potential of individuals. However, our results demonstrate that those individuals who take part in active-based entrepreneurship courses do not seem to decrease their entrepreneurial potential, as do their colleagues who participate in lecture-based entrepreneurship courses only.

The more specific objective of our study is to investigate the impact of different pedagogical approaches on the development of personal attributes and perceived skills related to entrepreneurship, and to investigate whether this development leads to increased entrepreneurial potential among higher education students. Based on our empirical evidence, entrepreneurship pedagogy seems to matter in the development of entrepreneurial potential. Indeed, it seems that active-based courses are well adapted for entrepreneurship education. In addition, entrepreneurial potential is best increased when educational programs target the improvement of entrepreneurial attitudes of the participants and their perceived skills in carrying out entrepreneurial activities.

While Walter, Parboteeah and Walter (2010) found out that active-based modes of entrepreneurship education have a stronger effect on entrepreneurial intention than reflective modes, in our study we found similar evidence but for active-based entrepreneurship pedagogy (i.e. a mix of project-based learning and traditional lectures). More specifically, our observations point out that active-based entrepreneurship pedagogy seems to influence attitudes, and therefore, instead 
of a direct effect, to have only indirect effect on the development of entrepreneurial intentions. This observation is in line with the study of Packham, Jones, Miller, Pickernell and Brychan (2010), who found earlier that enterprise education has a positive impact on entrepreneurial attitude. The impact of active-based pedagogies on attitudes is a particularly positive signal for those struggling to develop and maintain an active approach to teaching entrepreneurship. Active methods such as project-based learning frequently require more resources than traditional lecturing-based courses; it would be difficult to justify the effort if active-based methods had no discernible effect.

It is also interesting to note that the only direct effect that active-based entrepreneurial courses had was on attitudes, and not on perceived behavioural control. The active-based entrepreneurial courses had only indirect effect on perceived behavioural control through the mediating role of attitudes. Similar mediating role for attitudes was also observed by Zampetakis, Kafetsios, Bouranta, Dewett and Moustakis (2009). In their study, attitudes towards entrepreneurship fully mediated the effects of creativity and proactivity on entrepreneurial intent.

In addition to the above main findings, other interesting observations are worth commenting. First, closer analysis indicated that entrepreneurial intentions decreased among students with high initial level of entrepreneurial intentions and increased among a group of those with low initial level of entrepreneurial intentions. This is curious because it seems to indicate that higher education programs have a tendency to equalize the level entrepreneurial intentions of young people over time, regardless of the starting point of each individual, as if there was some kind of an equilibrium point towards which entrepreneurial intentions gear over time in higher education programs.

Second, those who arrive to higher education programs with high entrepreneurial potential end up lowering their potential (see also Fayolle et al., 2005). This observation seems not to be very promising from the point of view of formation of entrepreneurial potential in higher education. Indeed, our results suggest that individuals at the beginning of their educational program seem to show a greater self-confidence in starting businesses than they do at the end of their educational program. However, it isn't untypical for people to overrate their intention to perform a distant action. Hence, an individual, at the time of starting his/her educational program, may overrate his intent to start a business after graduation, whereas at the time of graduation and closer to the actual event, the student is more definite about his intentions. Indeed, our observations could suggest that the entrepreneurial potential of these individuals becomes more realistic over time: younger people understand better their career options, their own competencies, and requirements of starting their own businesses as a result of going through an educational program. And vice versa for some young people, who start their educational program with lower level of entrepreneurial potential: they 
discover entrepreneurship as one potential option in the future, and therefore their level of entrepreneurial potential goes up over time during the educational program. Unfortunately, the arrival level of intentions remained at relatively low level for young people whose intentions were developed from low to significantly higher level over time. That is, even for those young people, whose initially low level of intentions were developed to significantly higher level, the arrival level did not indicate strong intentions to start one's own business. This observation could suggest that strategic emphasis on entrepreneurship in the studied university still has work to do before it succeeds to develop entrepreneurial potential among its students.

So, what does increase entrepreneurial potential in individuals? Our empirical observations suggest that changes in attitudes and perceived behavioural control, but not in subjective norm, had a significant and positive impact on the development of entrepreneurial intentions, and therefore on entrepreneurial potential. Hence, we find our results in contradiction to e.g. those of Engle and his colleagues (2010) who, based on their multicountry study, argue that antecedents vary from one country context to another, but that subjective norm is consistently a contributor to entrepreneurial intentions. Based on our observations we can join Boissin et al. (2009) in questioning the influence of subjective norm in the TPB model; the explanatory power of subjective norm cannot be confirmed by our data. However, it is encouraging to note that attitudes and perceived behavioral control - both factors at least theoretically within the scope of influence of higher education programs - contribute to change in entrepreneurial potential. This signifies that in order to increase the entrepreneurial potential, we should focus on improving the knowledge base of young people (to change their attitudes) and put the young people into pedagogical situations where they can develop their skills and competencies in entrepreneurship related tasks (to improve their perceived behavior control).

Finally, the development of entrepreneurial potential among young women and men seems to be driven by different mechanisms, at least according to our observations. Our empirical model of entrepreneurial potential explained $28 \%$ of the variance among male students, and only $19 \%$ among female students. While men seem to follow the general model discussed above, women seem to demonstrate some independence vis-à-vis active-based pedagogy since it does not seem to cause any changes in their entrepreneurial attitudes. Also, changes in the women's entrepreneurial attitudes do not have any impact on changes in the perceived behavioral control. Therefore, those who plan and design entrepreneurship related initiatives to support the development of entrepreneurial potential should bear in mind that women and men do not seem to react in uniform fashion vis-à-vis these initiatives. One possibility is that women are more at home with lecturing- 
based pedagogy than men; the growing proportion of women in tertiary education may indicate this. In the EU on average, 124 women were enrolled in tertiary education for every 100 men in 2009 (Eurostat 2012). If entrepreneurial attitudes and skills are best learned in active-based settings, this may favour impacts on men rather than women from entrepreneurship education. Earlier studies have also found differences in learning style between men and women (Gallos, 1993). For example, Kaenzig et al. (2007) called into question the effectiveness and value of group work especially for women students, because women were not happy with their group work in business classes. Usually active-based entrepreneurial courses will be implemented as a group work. Some entrepreneurship studies have also found the different effects of women and men. Also and Isaksen (2012), for instance, found that among Norwegian female pupils at upper secondary school youth enterprise experience had an indirect positive effect on entrepreneurial intentions through its effect on

subjective norm and perceived behavioral control. A recent European Commission (2012) study on alumni of entrepreneurship programs found that female alumni score lower on entrepreneurial selfefficacy than their male counterparts, but higher than the control group. Wilson et al. (2007) found that effects of entrepreneurship education in MBA programs on entrepreneurial self-efficacy proved stronger for women than for men. Kickul et al.'s study (2008) also indicated that self-efficacy seemed to have a stronger effect on entrepreneurial interest for girls than for boys. Yordanova and Tarrazon (2010) found that gender effect on entrepreneurial intentions is fully mediated by perceived behavioral control and partially mediated by perceived subjective norms and attitudes. To conclude, a more individualized approach, allowing for the differences in preferences might benefit women. Also, an effort should be made to discover whether there are differences within activebased methodologies; if group work doesn't work well for female students, other active-based methods might be beneficially employed.

In the study at hand, however, it should be acknowledged that the observed difference in impact of active-based pedagogy may relate to work experience as well as gender. The men in the sample had more work experience. The greater practical experience could arguably enable them to better benefit from active-based pedagogy.

\section{Limitations and future studies}

While we believe that the results presented herein add to our understanding of the role of entrepreneurship education play in the development of entrepreneurial potential in higher education contexts, we acknowledge that the present research is not entirely beyond reproach. From a 
theoretical standpoint, we limited our efforts to investigate the effect of entrepreneurial education on the development of entrepreneurial potential. We do acknowledge that the entrepreneurial potential among young people can be fostered also through other means, such as traineeships and work experience is start-ups and small firms. We encourage future scholarly efforts to investigate those other means and their role in fostering entrepreneurial potential among young people. At the same time, we limited our focus on one intention model when other possible approaches could have been available to study the development of entrepreneurial potential. Again, future scholarly work could complement our results by investigating the same phenomenon through other theoretical lenses.

From an empirical standpoint, our sample was limited to only one university in a country, which has more than 40 universities. Increasing our knowledge of the potential effects of the general environmental and cultural contexts on the formation of entrepreneurial intentions requires further research using versatile samples comprising university students in other regions.

Longitudinal designs are quite demanding. The loss of data is problematic also in our study (534 respondents on 2008, 197 respondents (same individuals) on 2010). The missing data can bias conclusions drawn from the study and the obvious disadvantage in the loss of information resulting from the reduced sample size.

Notwithstanding these limitations, we believe that our findings add to the body of literature on how to develop entrepreneurial potential among young people. We believe that our findings add to what we, as a scholarly community, know about the development of entrepreneurial potential among younger individuals, and hope that both academics and practitioners may benefit from them. The pedagogical aspect of entrepreneurship related education is a particularly important for the development of entrepreneurial potential, yet it has been largely ignored in the entrepreneurship literature. By investigating the impact of different pedagogical approaches on the development of personal attributes and perceived skills related to entrepreneurship, our study is among the first ones to provide empirical evidence about their influence on the development of entrepreneurial potential. Ultimately, we hope to have added richness to the ongoing discussion among academics and practitioners alike regarding the importance of the development of entrepreneurial potential among younger people. 


\section{References}

Ajzen, I. (1991), "The Theory of Planned Behavior", Organizational Behavior and Human Decision Processes, Vol. 50, No. 2, pp. 179-211.

Ajzen, I. and Fishbein, M. (2004). "Questions Raised by Reasoned Action Approach: Comment on Odgen (2003)", Health Psychology, Vol. 23 No. 4, 431-434.

Also G. and Isaksen, E. (2012), "Closing the gender gap? Entrepreneurial training and entrepreneurial intentions among male and female youth", A paper presented at $17^{\text {th }}$ Nordic Conference on Small Business Research, Helsinki, Finland, May 23-25, 2012.

Arbuckle, J. (2007), Amos 18 User's Guide. Chicago. Amos Development Corporation.

Armitage, C.J. and Conner, M. (2001), "Efficacy of the Theory of Planned Behaviour: a Metaanalytic Review”, British Journal of Social Psychology, Vol. 40, pp. 471-499.

Autio, E., Keeley, H., Klofsen, G., Parker, C. and Hay, M. (2001), "Entrepreneurial intent among students in Scandinavia and in the USA", Enterprise and Innovation Management Studies, No. 2, pp. $145-160$.

Autio, E., Keeley, R., Klofsten, M. and Ulfstedt, T. (1997), "Entrepreneurial intent among students: testing an intent model in Asia, Scandinavia, and USA”, in Sexton, D.L. \& Kasarda, J.D. (Eds), Frontiers of Entrepreneurial Research, Babson College Publications, Wellesley, MA, pp. 133147.

Bagozzi, R., Baumgartner, H. and Yi, Y. (1989), "An investigation into the role of intentions as mediators of the attitude-behavior relationship", Journal of Economic Psychology, Vol. 10, pp. $35-62$.

Bandura, A. (1982), "Self-efficacy: toward a unifying theory of behavioral change", Psychological Review, Vol. 84, pp. 191-215.

Bandura, A., Adams, N., Hardy, A. and Howells, G. (1980), “Test of the generality of self-efficacy theory", Cognitive Therapy and Research, No. 4, pp. 39-66.

Bennett, R. (2006), "Business lecturers' perceptions of the nature of entrepreneurship", International Journal of Entrepreneurial Behaviour \& Research, Vol. 12 No. 3, pp. 165-188.

Blanchflower, D. and Meyer, B. (1994), “A longitudinal analysis of the young self-employed in Australia and the United States”, Small Business Economics, Vol. 6, No. 1, pp. 1-19.

Boissin, J-P., Branchet, B., Emin, S. and Herbert, J. I. (2009). "Students and entrepreneurship: A comparative study of France and the United States", Journal of Small Business and Entrepreneurship, Vol. 22, No. 2, pp. 101-122. 
Clarke, P. (2004), "Causal Analysis of Individual Change Using the Difference Score", Epidemiology, Vo. 15, No. 4, pp. 414-421.

Crant, M. (1996), “The proactive personality scale as a predictor of entrepreneurial intentions", Journal of Small Business Management, Vol. 34, No. 3, pp. 42-49.

Dana, L. (1987), “Towards a skills model for entrepreneurs", Journal of Small Business and Entrepreneurship, Vol. 5, No. 1, pp. 27-31.

Devonish, D, Alleyne, P., Charles-Soverall, W., Young Marshall, A. and Pounder, P. (2010), "Explaining entrepreneurial intentions in the Caribbean", International Journal of Entrepreneurial Behavior and Research, Vol. 16, No. 2, pp. 149-171.

Drost, E. and McGuire, J. (2011), "Fostering entrepreneurship among Finnish business students: Antecedents of entrepreneurial intent and implications for entrepreneurship education", International Review of Entrepreneurship, Vol. 9, No 2.

Engle, R. L., Dimitriadi, N., Gavidia, J. V., Schlaegel, C., Delanoe, S., Alvarado, I., He, X., Buame, S. and Wolff, B. (2010), “Entrepreneurial Intent. A Twelve-country Evaluation of Ajzen's Model of Planned Behaviour", International Journal of Entrepreneurial Research, Vol 16, No. 1, pp. 35-57.

Ertuna, Z. and Gurel, E. (2011), "The moderating role of higher education on entrepreneurship", Education \& Training, Vol. 53, No. 5.

European Commission (2012), "Effects and impact of entrepreneurship programmes in higher education”, DG for Enterprise and Industry, Entrepreneurship Unit, Brussels, March 2012, 87 pgs.

Eurostat (2012), "Key data on education in Europe 2012”, Education, Audiovisual and Culture Executive Agency, Brussels, February 2012, 212 pgs.

Fayolle, A. (2005), "Evaluation of Entrepreneurship Education: Behaviour Performing or Intention Increasing?", Entrepreneurship and Small Business, Vol. 2, No. 1, pp. 89-98.

Fayolle A., Gailly B. and Lassas-Clerc N. (2005), "The long-Term Effect of Entrepreneurship Teaching Programmes on Entrepreneurial Intention”, RENT XIX Conference, Naples, Italy, November 17-18, 2005.

Fishbein, M. and Ajzen, I. (1975), Belief, Attitude, Intention, and Behavior: An Introduction to Theory and Research, Reading, MA, Addison-Wesley.

Franco, M., Haase, H. and Lautenschläger, A. (2010), “Students' entrepreneurial intentions: an inter-regional comparison", Education + Training, Vol. 52, No. 4, pp. 260-275. 
Gallos, J. (1993), “Women's experiences and ways of knowing: Implications for teaching and learning in the organizational behavior classroom”, Journal of Management Education, Vol. 17, pp. $7-26$.

Gibb, A. (2002), 'In pursuit of a new 'enterprise' and 'entrepreneurship' paradigm for learning: creative destruction, new values, new ways of doing things and new combinations of knowledge", International Journal of Management Reviews, Vol. 3, No. 4, pp. 233-269.

Gibb, A. (1996), "Entrepreneurship and small business management: can we afford to neglect them in the twenty-first century business school?", British Journal of Management, Vol. 7, No 4, pp. 309-321.

Harman, H. H. (1976). Modern Factor Analysis, 3rd edition. Chicago, University of Chicago Press.

Harte, C. and Stewart, J. (2010), "Undertaking HRD research in higher education. A longitudinal approach to evaluating undergraduate "enterprise education" modules", Education + Training, Vol. 52, No. 8/9, pp. 679-693.

Henley, A. (2005), "From entrepreneurial aspiration to business start-up: evidence from British longitudinal study", Academy of Entrepreneurship Journal, Vol. 10, No. 1-2.

Henley, A. (2007), "Entrepreneurial aspiration and transition into self-employment: evidence from British longitudinal data", Entrepreneurship \& Regional Development, Vol. 19, No. 3, pp.253280.

Henry, C. and Treanor, L. (2012), "Exploring entrepreneurship education within veterinary medicine: can it be taught?", Journal of Small Business and Enterprise Development, Vol. 19, No. 3, pp. 484-499.

Hytti, U., Stenholm, P. Heinonen, J. and Seikkula-Leino, J. (2010), "Perceived learning outcomes in entrepreneurship education: The impact of student motivation and team behavior", Education + Training, Vol. 52, No. 8, pp. 587-606.

Jones, P., Jones, A., Packham, G. and Miller, C. (2008), "Student attitudes towards enterprise education in Poland: a positive impact", Education + Training, Vol. 50, No. 7, pp. 597-614

Jones, B. and Iredale, N. (2010), "Enterprise education as pedagogy", Education + Training, Vol. 52, No. 1, pp. 7-9.

Kaenzig, R., Hyatt, E. and Anderson, S. (2007), “Gender differences in college business educational experiences", Journal of Education for Business, No. November/December, pp. 95-100.

Kautonen, T. Luoto, S. and Tornikoski, E. (2010), "Influence of work history on entrepreneurial intentions in "prime age" and "third age", International Small Business Journal, Vol. 28, No. 6, pp. 583-601. 
Kautonen, T., van Gelderen, M. and Tornikoski, E. (2013), "Predicting entrepreneurial behavior: A test of the theory of planned behavior", Applied Economics, Vol. 45, No. 6, pp. 697-707.

Kickul, J., Wilson, F., Marlino, D. and Barbosa, S. (2008), “Are misalignments of perceptions and self-efficacy causing gender gaps in entrepreneurial intentions among our nation's teens?" Journal of Small Business and Enterprise Development, Vol. 15, No. 2, pp. 321-335.

Kolvereid, L. (1996), "Prediction of Employment Status Choice Intentions", Entrepreneurship Theory and Practice, Vol. 21 No. 1, pp. 47-57.

Kourilsky, M. and Walstad, W. (1998), "Entrepreneurship and female youth: knowledge, attitudes, gender difference, and educational practices", Journal of Business Venturing, Vol. 13, pp. 7788.

Kristiansen, S. and Indarti, N. (2004), "Entrepreneurial intention among Indonesian and Norwegian students", Journal of Enterprising Culture, Vol. 12, No. 1, pp. 55-78.

Krueger, N. (1993), “The impact of prior entrepreneurial exposure on perceptions of new venture feasibility and desirability”, Entrepreneurship Theory and Practice, Vol. 18, No. 1, pp. 5-21.

Krueger, N.F. and Brazeal, D.V. (1994), "Entrepreneurial potential and potential entrepreneurs", Entrepreneurship Theory and Practice, Spring, pp. 91-104.

Krueger, N. F., and Carsrud, A. L. (1993), "Entrepreneurial Intentions: Applying the Theory of Planned Behavior”, Entrepreneurship and Regional Development, Vol. 5, No. 4, pp. 315-330.

Krueger, N., Reilly, M. and Carsrud, A. (2000), “Competing Models of Entrepreneurial Intentions", Journal of Business Venturing, Vol. 15, No. 2, pp. 411-432.

Lanero, A., Vazquez, J. Gutierrez, P. and Purificación Garcia M. (2011), "The impact of entrepreneurship education in European universities: an intention-based approach analyzed in the Spanish area", International Review on Public and Nonprofit Marketing, Vol. 8, No, 2, pp. $111-130$

Lee, L. Wong, P., Foo, M. and Leung, A. (2011), "Entrepreneurial intentions: The influence of organizational and individual factors", Journal of Business Venturing, Vol. 6, No, 1, pp. 124136.

Linan, F. (2004), "Intention-based models of entrepreneurship education", Proceedingds of International Conference, 4-7 July 2004, Naples, Italy.

Linan, F. and Chen, Y-W. (2009), "Development and cross-cultural application of a specific instrument to measure entrepreneurial intentions", Entrepreneurship Theory and Practice, Vol. 33, No, 3, pp. 593-617. 
Matlay, H. (2005), "Researching entrepreneurship and education. Part 1: What is entrepreneurship and does it matter?", Education + Training, Vol. 47, No. 8/9, pp. 665-677.

Matlay, H. (2008), "The impact of entrepreneurship education on entrepreneurial outcomes", Journal of Small Business and Enterprise Development Vol. 15, No. 2, pp. 382-396.

Matlay, H., and Carey, C. (2007), "Enterpreneurship education in the UK: a longitudinal perspective", Journal of Small Business and Enterprise Development, Vol. 14, No, 2, pp. 252263.

Millman, C., Li, Z., Matlay, H. \& Wong, W-C. (2010), 'Entrepreneurship education and students' internet entepreneurship intentions: evidence from Chinese HEIs", Journal of Small Business and Enterprise Development, Vol. 17, No. 4, pp. 569-590.

Mwasalwiba, E. (2010), "Entrepreneurship education: a review of its objectives, teaching methods, and impact indicators", Education + Training, Vol. 52, No. 1, pp. 20-47.

Nabi, G., Holden, R. and Walmsley, A. (2010), "From student to entrepreneur: towards a model of graduate entrepreneurial career-making”, Journal of Education and Work, Vol. 23, No. 5, pp. $389-415$.

Neck, H. and Greene, P. (2011), "Entrepreneurship education: known worlds and new frontiers", Journal of Small Business Management, Vol. 49, No. 10, pp. 55-70.

Oosterbek, H. van Praag, M. and Ijsselstein, A. (2010), “The impact of entrepreneurship education on entepreneurship skills and motivation", European Economic Review, Vol. 54, No. 3, pp. $442-454$.

Packham, G., Jones, P., Miller, C., Pickernell, D. and Brychan, T. (2010), “Attitudes towards entrepreneurship education: a comparative analysis", Education and Training, Vol. 52, No. 8/9, pp. 568-586.

Pihkala, J. (2008), "Ammattikorkeakoulutuksen aikaiset yrittäjyysintentioiden muutokset", Opetusministeriön julkaisuja 2008:1, Helsinki.

Pihkala, J. and Miettinen, A. (2004), "Exploring changes in entrepreneurial intentions - a follow-up study in two polytechnics", Proceedings of International Entrepreneurship Conference 5-7 July 2004, Naples, Italy.

Pittway, L. \& Cope, J. (2007), "Entrepreneurship education: a systematic review of the evidence", International Small Business Journal, Vol. 25, No. 5, pp 479-510.

Podsakoff, P. M., MacKenzie, S. B., Lee, J.-Y. and Podsakoff, N. P. (2003), "Common method biases in behavioral research: A Critical Review of the Literature and Recommended Remedies", Journal of Applied Psychology, Vol. 88, No. 5, pp. 879-903. 
Podsakoff, P., and Organ, D. (1986), "Self-reports in organizational research: Problems and prospects", Journal of Management, Vol. 12, No. 2, pp. 531-544.

Pruett, M., Shinnar, R., Toney, B., Llopis, F. and Fox, J. (2009), "Explaining entrepreneurial intentions of university students: a cross-cultural study", International Journal of Entrepreneurial Behaviour \& Research, Vol. 15, No. 6, pp. 571-594.

Raab, G., Stedham, Y. and Neuner, M. (2005), "Entrepreneurial potential: An exploratory study of business students in the U.S. and Germany", Journal of Business and Management, Vol. 11, No. 2, pp. 71-88.

Sandhu, M., Sidique, S. \& Riaz, S. (2011), "Entrepreneurship barriers and entrepreneurial inclination among Manalysian postgratuate students", International Journal of Entrepreneurial Behaviour \& Research, Vol. 17, No. 4, pp. 428-449.

Segal, G., Borgia, D. and Schoenfeld, J. (2005), The motivation to become an entrepreneur. International Journal of Entrepreneurial Behavior and Research, Vol. 11, No. 1, pp. 42-57.

Sequeira, J., Mueller, S. and Mcgee, J. (2007), "The influence of social ties and self-efficacy in forming entrepreneurial intentions and motivating nascent behavior”, Journal of Developmental Entrepreneurship, Vol. 12, No. 3, pp. 275-293.

Shapero, A. and Sokol, L. (1982), “The social dimensions of entrepreneurship”, in Kent, C., Sexton, D. and Vesper, K. (Eds), The Encyclopedia of Entrepreneurship, Prentice-Hall, Englewood Cliffs NY, pp. 72-90.

Shay, J. and Terjesen, S. (2005), "Entrepreneurial aspirations and intentions and intentions of business students: a gendered perspective", A paper presented at the Babson Entrepreneurship Conference, Boston MA.

Souitaris, V., Zerbinati, S. and Al-Laham, A. (2007), "Do entrepreneurship programmes raise entrepreneurial intention of scienc and engineering students? The effect of learning, inspiration and resources", Journal of Business Venturing, Vol. 22, No. 4, pp. 566-591.

Steiner, D. (2005), "Finding our way: An Introduction to Path Analysis", Canadian Journal of Psychiatry, Vol. 50, No. 2, pp. 115-122.

Swan, W., Chang-Schneider, C. and McClarity, K. (2007), "Do people's self-views matter?" American Psychologist, Vol. 62, No. 2, pp. 84-94.

Thompson, J. (2004) "The facets of the entrepreneurs: identifying entrepreneurial potential", Management Decision Vol. 42, No. 1/2, pp. 243-258.

Tkachev, A. and Kolvereid. L. (1999), "Self-employment Intentions among Russian Students", Entrepreneurship \& Regional Development, Vol. 11, pp. 269-280. 
Tornikoski, E. and Kautonen, T. (2009), "Enterprise as sunset career? Entrepreneurial intentions in the ageing population", International Journal of Entrepreneurship and Small Business, Vol. 8, No. 2, pp. 278-290.

van Gelderen, M, (2010), “Autonomy as the guiding aim of entrepreneurship education”, Education + Training, Vol. 52, No. 8/9, pp. 710-721.

Van Gelderen, M. and Jansen, P. (2006), “Autonomy as a start-up motive”, Journal of Small Business and Enterprise Development, Vol. 13, No. 1, pp. 23-32.

Walter, S., Parboteeah, K. and Walter, A. (2010), "Entrepreneurship resources of university departments, individual influences, and students' entrepreneurial intentions: a cross-level analysis", Best Paper Proceedings of 2010 Academy of Management meeting in Montreal.

Wang, C. and Wong, P. (2004) "Entrepreneurial interest of university students in Singapore", Technovation, Vol. 24. No. 2, pp. 161-172.

Wilson, F., Marlino, D. and Kickul, J. (2004), “Our entrepreneurial future: examining the diverse attitudes and motivations of teens across gender and ethnic identity", Journal of Development Entrepreneurship, Vol. 9, No. 3, pp. 177-197.

Wilson, F., Kickul, J. and Marlino, D. (2007), "Gender, entrepreneurial self-efficacy, and entrepreneurial career intentions: Implications for entrepreneurship education”, Entrepreneurship Theory and Practice, Vol. 31, No. 3, pp. 387-406.

Wilson, F., Kickul, J., Marlino, D., Barbosa, S. and Griffiths, M. (2009), “An analysis of the role of gender and self-efficacy in developing female", Journal of Developmental Entrepreneurship, Vol. 14, No. 2, pp. 105-119.

$\mathrm{Wu}, \mathrm{S}$. and $\mathrm{Wu}, \mathrm{L} .2008$, "The impact of higher education on entrepreneurial intentions of university students in China", Journal of Small Business and Enterprise Development, Vol 15, No. 4, pp. 640-655

Yordanova, D. and Tarrazon, M-A. (2010), "Gender differences in entrepreneurial intentions: evidence from Bulgaria”, Journal of Developmental Entrepreneurship, Vol. 15, No. 3, pp. 245261 .

Zampetakis, L., Kafetsios, K., Bouranta, N., Dewett, T. and Moustakis, V. (2009), "On the relationship between emotional intelligence and entrepreneurial attitudes and intentions", International Journal of Entrepreneurial Behaviour \& Research, Vol. 15, No. 6, pp. 595-618.

Zhao, H., Seibert, S. and Hills, G. (2005), "The Mediating Role of Self-Efficacy in the Development of Entrepreneurial Intentions”, Journal of Applied Psychology, Vol. 90, pp. 12651272. 


\section{Acknowledgements}

This research project has been funded by European Regional Development Fund and the support is gratefully acknowledged. 
Appendix 1. Variables and their items.

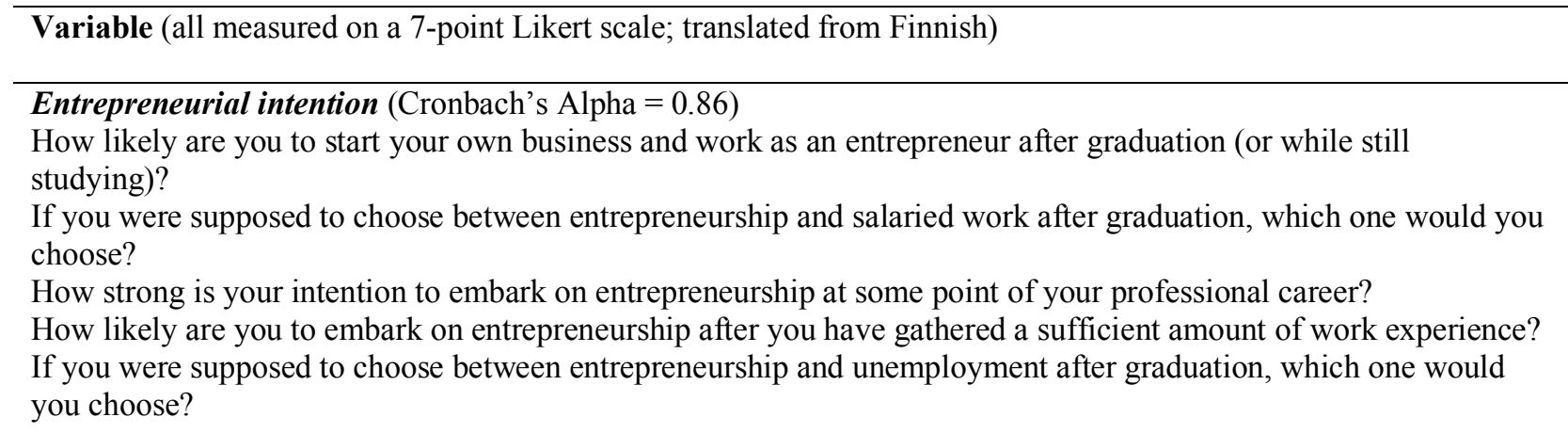

Subjective norm* (Cronbach's Alpha $=0.73$ )

I believe that my closest family members think I should not/should strive to start my own business and to work as an entrepreneur after graduation.

How much attention do you pay to what your closest family members think if you strive to start your own business and to work as an entrepreneur after graduation?

I believe that my best friends think I should not / should strive to start my own business and to work as an entrepreneur after graduation.

How much attention do you pay to what your best friends think if you strive to start your own business and to work as an entrepreneur after graduation?

I believe that my significant others think I should not / should strive to start my own business and to work as an entrepreneur after graduation.

How much attention do you pay to what your significant others think if you strive to start your own business and to work as an entrepreneur after graduation?

Perceived behavioural control (Cronbach's Alpha $=0.71$ )

If I established a business and started to work as an entrepreneur after graduation, my chance of success would be (good / bad)

If I really wanted to, I could easily start a business and work as an entrepreneur after graduati

There are very few / numerous things that are beyond my own control but could prevent me from starting my own business and working as an entrepreneur after graduation.

For me, starting my own business and working as an entrepreneur after graduation (very easy / very difficult)

If I established my own business and started to work as an entrepreneur after graduation, my risk of failure would be (very small / very big)

Attitudes towards entrepreneurship (Cronbach's Alpha $=0.75$ )

To what extent do the following attributes correspond to your perceptions of entrepreneurship (i.e. establishing a business and working as an entrepreneur)? (not at all - completely)

Interesting

Esteemed

Worth pursuing

Boring

Fascinating

Despised

Good income level

\footnotetext{
* For the statistical analysis the scales were transformed to $-3-+3$ scale. In addition, motivation to comply was measured by three items (seven-point scale from 1 to 7) referring to each of the aforementioned belief questions. The belief based items (coded as ranging from -3 to 3 ) and the corresponding motivation to comply items (coded as ranging from 1 to 7) were multiplied, and then added to create an index of Subjective Norm
} 
Appendix 2. Correlations between the main variables.

Correlations among the scales (2008 data)

\begin{tabular}{|c|c|c|c|c|c|}
\hline & & $\begin{array}{l}\text { Entrepreneurial } \\
\text { Intentions }\end{array}$ & $\begin{array}{l}\text { Subjective } \\
\text { Norm }\end{array}$ & $\begin{array}{c}\text { Entrepreneurial } \\
\text { Attitudes }\end{array}$ & $\begin{array}{c}\text { Perceived } \\
\text { Behavioral } \\
\text { Control }\end{array}$ \\
\hline Entrepreneurial Intentions & $\begin{array}{l}\text { Pearson Correlation } \\
\text { Sig. (2-tailed) } \\
\text { N }\end{array}$ & $\begin{array}{r}1 \\
197\end{array}$ & & & \\
\hline Subjective Norm & $\begin{array}{l}\text { Pearson Correlation } \\
\text { Sig. (2-tailed) } \\
\mathrm{N}\end{array}$ & $\begin{array}{r}.214^{* *} \\
.003 \\
197\end{array}$ & $\begin{array}{r}1 \\
197\end{array}$ & & \\
\hline Entrepreneurial Attitudes & $\begin{array}{l}\text { Pearson Correlation } \\
\text { Sig. (2-tailed) } \\
\mathrm{N}\end{array}$ & $\begin{array}{r}.502^{\star *} \\
.000 \\
197\end{array}$ & $\begin{array}{l}.100 \\
.163 \\
197\end{array}$ & $\begin{array}{r}1 \\
197\end{array}$ & \\
\hline $\begin{array}{l}\text { Perceived Behavioral } \\
\text { Control }\end{array}$ & $\begin{array}{l}\text { Pearson Correlation } \\
\text { Sig. (2-tailed) } \\
\text { N }\end{array}$ & $\begin{array}{r}.545^{\star *} \\
.000 \\
197\end{array}$ & $\begin{array}{r}-.056 \\
.433 \\
197\end{array}$ & $\begin{array}{r}.475^{\star *} \\
.000 \\
197\end{array}$ & $\begin{array}{r}1 \\
197\end{array}$ \\
\hline
\end{tabular}

**. Correlation is significant at the 0.01 level (2-tailed).

Correlations among the scales (2010 data)

\begin{tabular}{|c|c|c|c|c|c|}
\hline & & $\begin{array}{l}\text { Entrepreneurial } \\
\text { Intentions }\end{array}$ & $\begin{array}{l}\text { Subjective } \\
\text { Norm }\end{array}$ & $\begin{array}{c}\text { Entrepreneurial } \\
\text { Attitudes }\end{array}$ & $\begin{array}{c}\text { Perceived } \\
\text { Behavioral } \\
\text { Control }\end{array}$ \\
\hline Entrepreneurial Intentions & $\begin{array}{l}\text { Pearson Correlation } \\
\text { Sig. (2-tailed) } \\
\mathrm{N}\end{array}$ & $\begin{array}{r}1 \\
197\end{array}$ & & & \\
\hline Subjective Norm & $\begin{array}{l}\text { Pearson Correlation } \\
\text { Sig. (2-tailed) } \\
\mathrm{N}\end{array}$ & $\begin{array}{c}.175^{*} \\
.014 \\
197\end{array}$ & $\begin{array}{r}1 \\
197 \\
\end{array}$ & & \\
\hline Entrepreneurial Attitudes & $\begin{array}{l}\text { Pearson Correlation } \\
\text { Sig. (2-tailed) } \\
\mathrm{N}\end{array}$ & $\begin{array}{c}.455^{* *} \\
.000 \\
196\end{array}$ & $\begin{array}{r}.059 \\
.412 \\
196\end{array}$ & $\begin{array}{r}1 \\
196\end{array}$ & \\
\hline $\begin{array}{l}\text { Perceived Behavioral } \\
\text { Control }\end{array}$ & $\begin{array}{l}\text { Pearson Correlation } \\
\text { Sig. (2-tailed) } \\
\mathrm{N}\end{array}$ & $\begin{array}{r}.503^{* *} \\
.000 \\
197\end{array}$ & $\begin{array}{r}-.033 \\
.648 \\
197\end{array}$ & $\begin{array}{r}.414^{* *} \\
.000 \\
196\end{array}$ & $\begin{array}{r}1 \\
197\end{array}$ \\
\hline
\end{tabular}

*. Correlation is significant at the 0.05 level (2-tailed).

**. Correlation is significant at the 0.01 level (2-tailed). 
Appendix 3. Intention development for different groups of young people.

initial level of intention

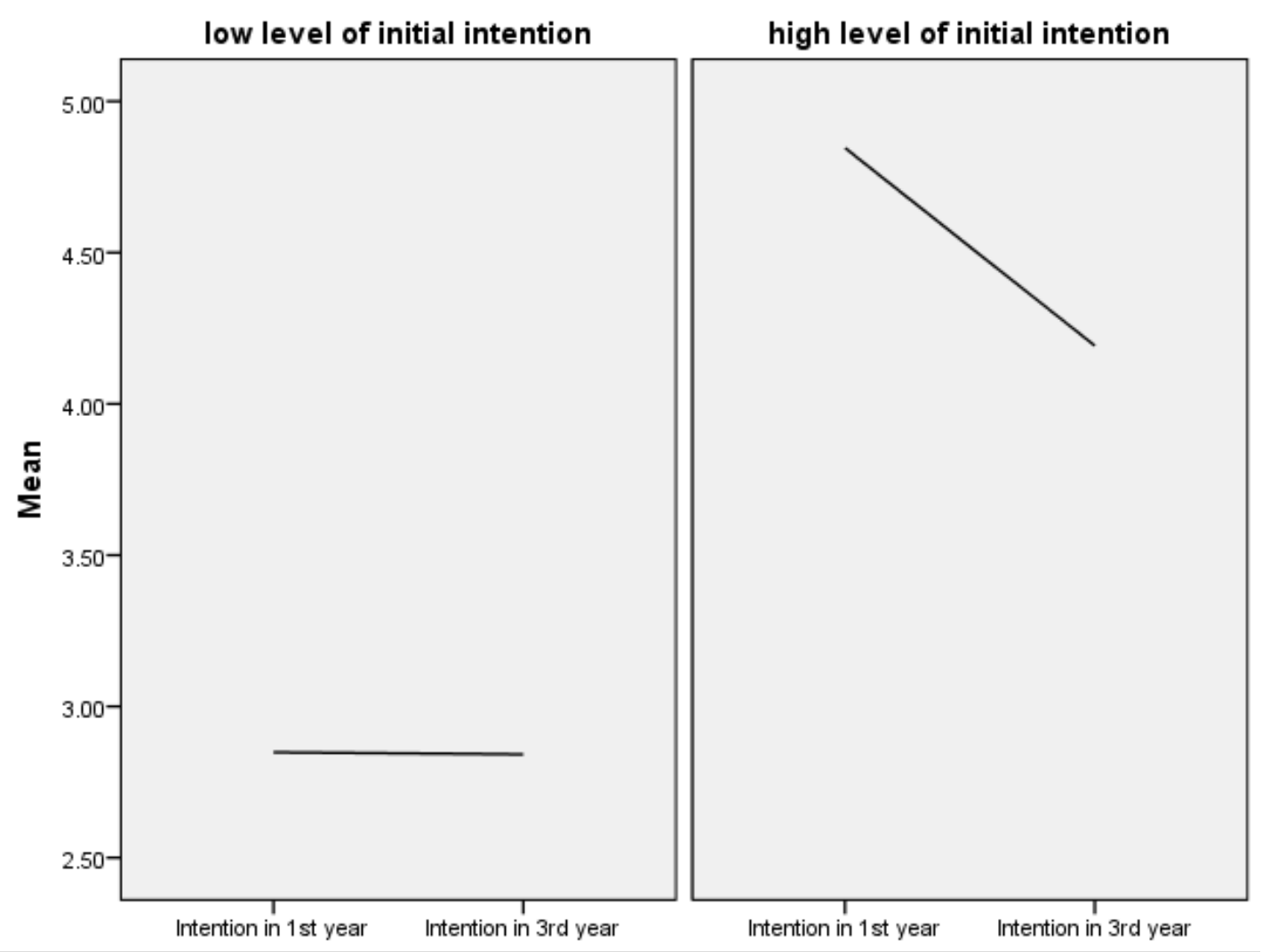

direction of change in $\mathrm{El}$

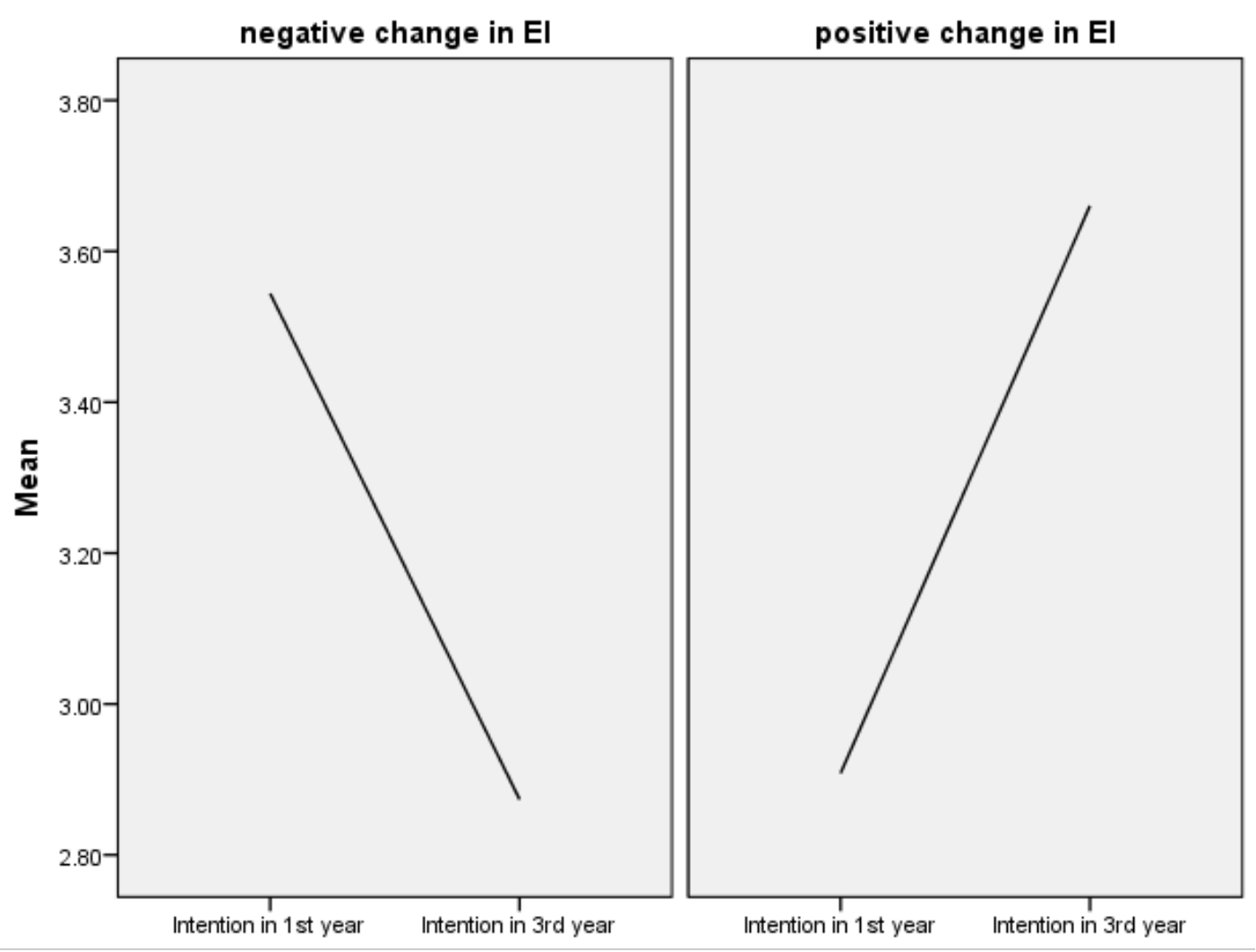


Appendix 4. The profiles of different groups of young people with intention development.

\begin{tabular}{|l|l|l|}
\hline & Group 1: Low initial level of intention & Group 2: High initial level of intention \\
\hline Earlier participation in entrepreneurship courses & $23 \%$ & $20 \%$ \\
\hline Earlier work experience (more than 6 months) & $50 \%$ & $50 \%$ \\
\hline Mother's professional background as an entrepreneur & $17 \%$ & $35 \%$ \\
\hline Father's professional background as an entrepreneur & $31 \%$ & $57 \%$ \\
\hline Male & $35 \%$ & $52 \%$ \\
\hline
\end{tabular}

\begin{tabular}{|l|l|l|}
\hline & Group 3: Negative change in intention & Group 4: Positive change in intention \\
\hline Earlier participation in entrepreneurship courses & $18 \%$ & $31 \%$ \\
\hline Earlier work experience (more than 6 months) & $47 \%$ & $55 \%$ \\
\hline Mother's professional background as an entrepreneur & $16 \%$ & $31 \%$ \\
\hline Father's professional background as an entrepreneur & $34 \%$ & $41 \%$ \\
\hline Male & $37 \%$ & $42 \%$ \\
\hline
\end{tabular}


Appendix 5. Correlations between the main change variables.

\begin{tabular}{|ll|r|r|r|r|r|}
\hline & & & \\
\hline & El change & ATT change & PBC change & SN change & $\begin{array}{c}\text { Active-based } \\
\text { entrep.pedagogy }\end{array}$ \\
\hline El change & Pearson Correlation & 1 & & & & \\
& Sig. (2-tailed) & & & & & \\
\hline ATT change & Pearson Correlation & $.339^{* *}$ & 1 & & & \\
& Sig. (2-tailed) & .000 & & & & \\
\hline PBC change & Pearson Correlation & $.388^{* *}$ & $.242^{* *}$ & & & \\
& Sig. (2-tailed) & .000 & .001 & & & \\
\hline SN change & Pearson Correlation & .111 & .015 & .015 & & \\
& Sig. (2-tailed) & .119 & .830 & .832 & & \\
\hline Active-based & Pearson Correlation & .161 & $.305^{*}$ & .154 & .010 & \\
entrep.pedagogy & Sig. (2-tailed) & .197 & .013 & .216 & .934 & \\
\hline
\end{tabular}

${ }^{* *}$. Correlation is significant at the 0.01 level (2-tailed).

*. Correlation is significant at the 0.05 level (2-tailed). 
Appendix 6. The empirical Intention Development model for female students.

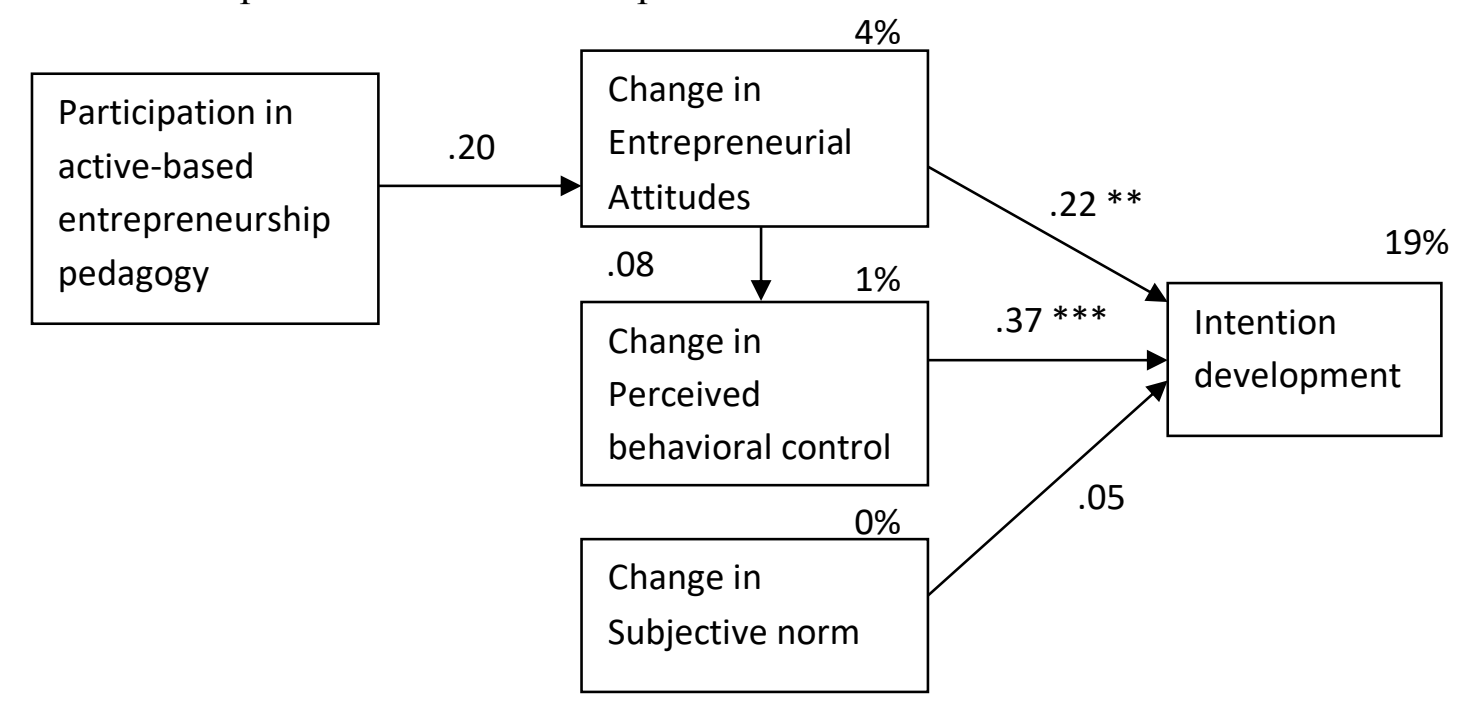

Notes: chi-square $=1.717, \mathrm{df}=5, \mathrm{p}=0.887, \mathrm{CMIN} / \mathrm{DF}=0.343, \mathrm{CFI}=1.000, \mathrm{NFI}=0.944, \mathrm{RMSEA}=0.000$

$+\mathrm{p}<.10 . * \mathrm{p}<.05 . * * \mathrm{p}<.01 . * * * \mathrm{p}<.001$

Estimates and Standardized Regression Weights (model for female students)

\begin{tabular}{|c|c|c|c|c|c|c|c|}
\hline & & & $\begin{array}{r}\text { Estim } \\
\text { ate }\end{array}$ & S.E. & C.R. & $\mathrm{P}$ & $\begin{array}{r}\text { Standardized regression } \\
\text { weights }\end{array}$ \\
\hline ATTchange & $<---$ & Ent. pedagogy &, 236 &, 179 & 1,317 &, 188 & ,200 \\
\hline PBCchange & $<---$ & ATTchange &, 109 &, 133 & ,819 &, 413 &, 075 \\
\hline EIchange & $<---$ & ATTchange &, 330 &, 126 & 2,619 & ,009 &, 216 \\
\hline EIchange & $<---$ & PBCchange & ,385 &, 087 & 4,430 & $* * *$ &, 365 \\
\hline EIchange & $<---$ & SNchange &, 003 &, 004 &, 667 &, 505 &, 055 \\
\hline
\end{tabular}


Appendix 7. The empirical Intention Development model for male students.

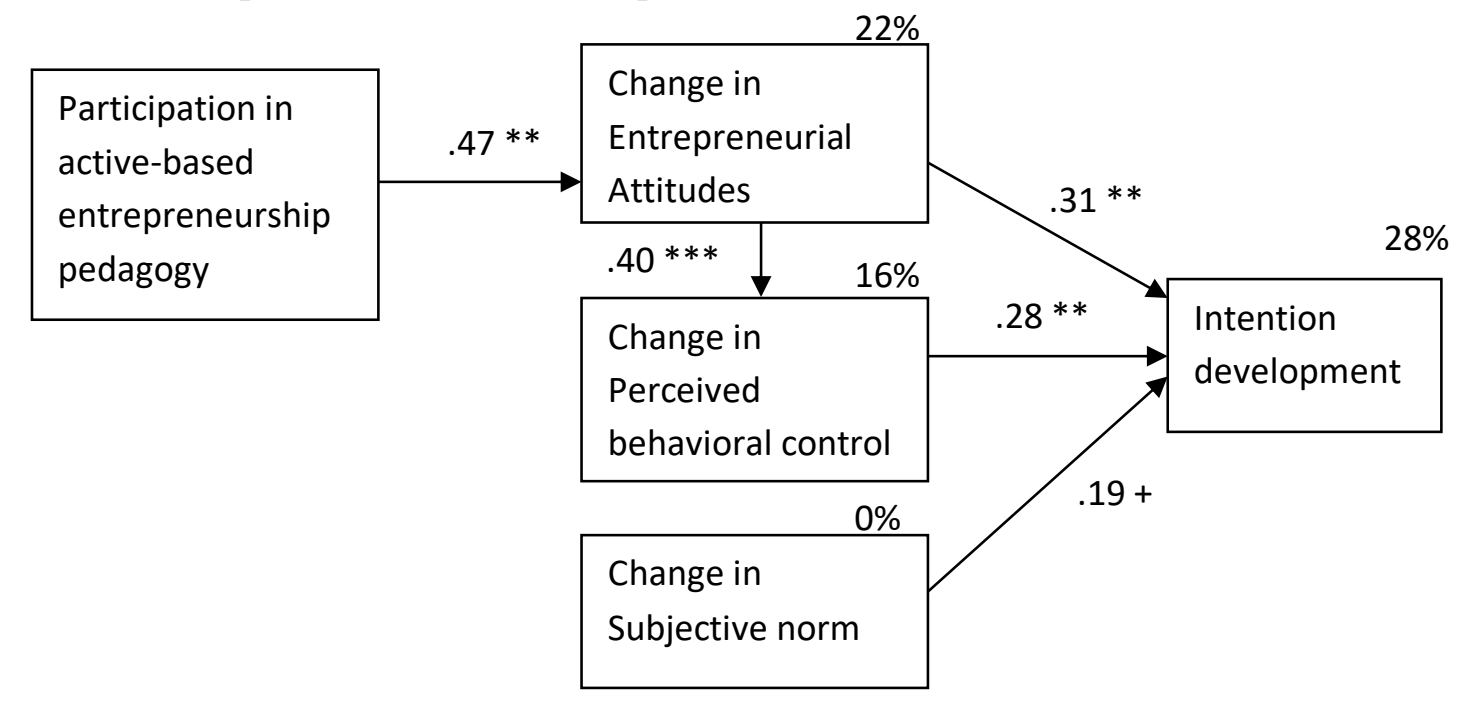

Notes: chi-square $=3.363, \mathrm{df}=5, \mathrm{p}=0.644, \mathrm{CMIN} / \mathrm{DF}=0.673, \mathrm{CFI}=1.000, \mathrm{NFI}=0.928, \mathrm{RMSEA}=0.000$

$+\mathrm{p}<.10{ }^{*} \mathrm{p}<.05 .{ }^{* *} \mathrm{p}<.01 .{ }^{* * *} \mathrm{p}<.001$

Estimates and Standardized Regression Weights (model for male students)

\begin{tabular}{llllllll}
\hline & & & Estimate & S.E. & C.R. & P & $\begin{array}{r}\text { Standardized regression } \\
\text { weights }\end{array}$ \\
\hline ATTchange & $<---$ & Ent. pedagogy &, 803 &, 259 & 3,102 &, 002 &, 474 \\
PBCchange & $<---$ & ATTchange &, 422 &, 111 & 3,784 & $* * *$ &, 400 \\
EIchange & $<---$ & ATTchange &, 352 &, 120 & 2,942 &, 003 &, 314 \\
EIchange & $<---$ & PBCchange &, 294 &, 113 & 2,604 &, 009 &, 277 \\
EIchange & $<---$ & SNchange &, 013 &, 007 & 1,953 &, 051 &, 190 \\
\hline
\end{tabular}

